\title{
The Genetics of Pituitary Adenomas
}

\author{
Monica Fedele, Giovanna Maria Pierantoni and Alfredo Fusco \\ Istituto di Endocrinologia e Oncologia Sperimentale (IEOS) del CNR, and Dipartimento \\ di Biologia e Patologia Cellulare e Molecolare, Università di Napoli Federico II \\ Italy
}

\section{Introduction}

Cancer is considered a disease of the genome since the development of the vast majority of the human neoplasias is due to the accumulation of gene mutations. Indeed, the vast majority of tumours occur due to a considerable number of mutations that human cells accumulate during lifetime. Approximately 380 genes, representing about $1 \%$ of all human genes, have been implicated via mutation in tumorigenesis (Futreal et al., 2004). Most (90\%), of these mutations are somatic, whereas germline mutations are a minority (20\%). Some mutations may be both somatic and germline (10\%) (Futreal et al., 2004).

Pituitary adenomas (PA) are one of the most frequent intracranial tumours with a prevalence of clinically-apparent tumours close to one in 1,000 of the general population and are the third most common intracranial tumour type after meningiomas and gliomas (Scheithauer et al., 2006). The majority of pituitary adenomas are sporadic and only a small subset (5\% of all pituitary tumours) are familial, and often occur as component of familial endocrine-related tumour syndromes. Despite their benign nature, PA can cause significant morbidity because of hormonal hyper-secretion, or compressive effects to surrounding tissues. For example, GH-producing adenomas are associated with a GH excess that leads to gigantism or acromegaly, depending on whether the excessive GH occurs prior or not to epiphyseal-plate closure, respectively. In addition, if the pituitary mass overgrows, it can impinge upon the optic chiasm interfering with vision or generally results in headache due to the increased pressure on the surrounding brain structures.

Therefore, molecular understanding of pituitary adenoma formation is essential for the development of medical therapies and the treatment of post-operative recurrences.

\section{The pituitary gland}

The pituitary gland, also known as hypophysis, is one of the most important glands of the mammalian endocrine system. Through its secreted hormones, it controls the growth and activity of other glands: the thyroid, the adrenals, the gonads, the liver, the adipose tissue and the mammary glands (Fig. 1). The pituitary does not act independently, but it is under the continuous control of the nervous system through the hypothalamus. A wide range of external stimuli, including supply of nutrients, the ambient temperature, the exercise, and physical or psycological stress, causes secretion of hypothalamic hormones. As a response to hypothalamic control, the pituitary secretes the hypophyseal hormones, which maintain 
crucial homeostatic functions, including metabolism, growth, and reproduction. Apart from the hypothalamic inputs, pituitary hormone secretion is also regulated by feedback effects of the circulating hormones, as well as the autocrine and paracrine secretions of the pituitary cells (Bilezikjian et al., 2004; Mechenthaler, 2008) (Fig. 1).

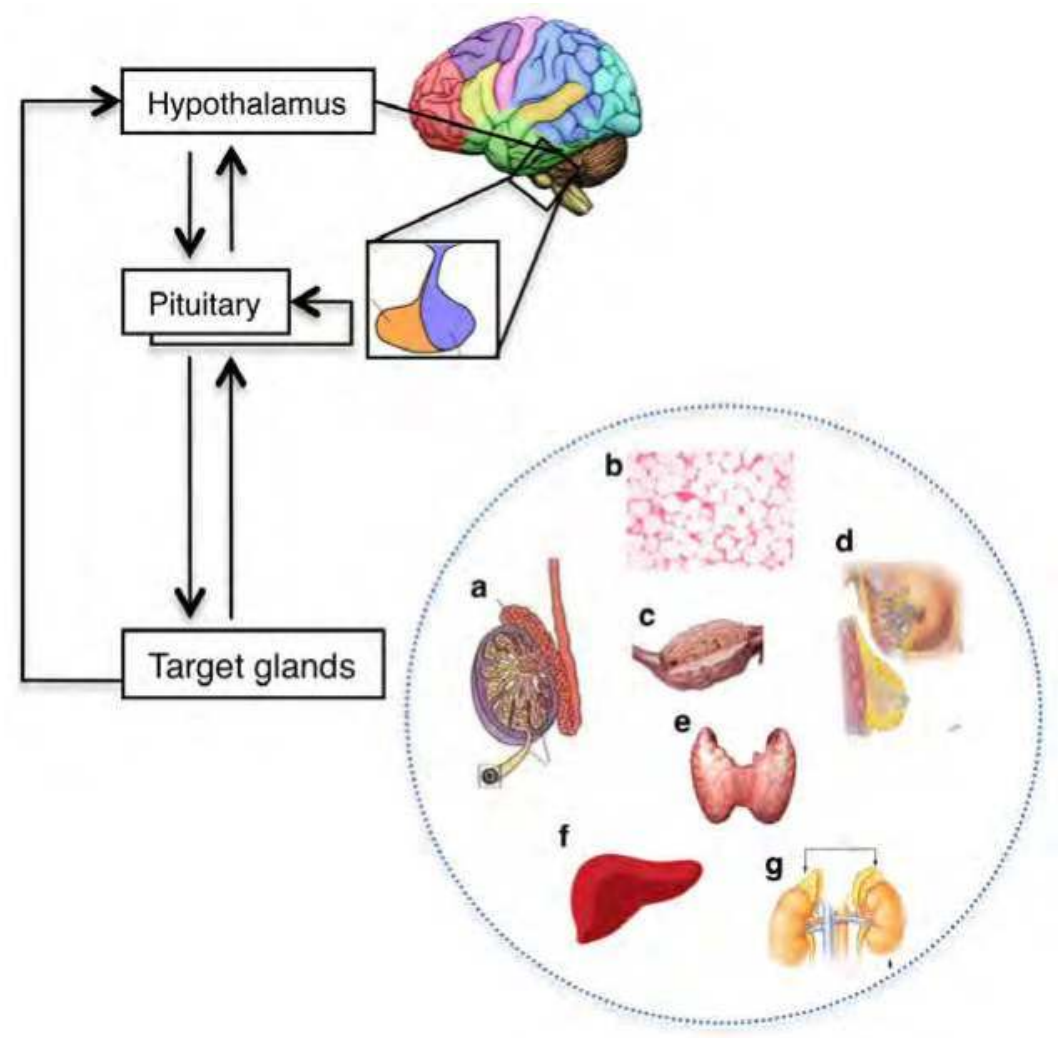

Fig. 1. Schematic representation of the hypothalamic-pituitary axis. Hypothalamic hormones, through the portal system, directly target anterior pituitary cell surface receptors that elicit positive or negative signals mediating pituitary hormone gene transcription and secretion. Pituitary hormones exert negative feedback on hypothalamus. Intrapituitary cytokines and growth factors regulate pituitary cell function by paracrine and autocrine control. Peripheral hormones from pituitary target glands exert negative feedback on respective pituitary hormone synthesis and secretion as well as on hypothalamic releasing factors. a, testis; b, adipose tissue; c, ovary; d, mammary gland; e, thyroid; f, liver; g, adrenal glands (arrows).

The human hypophysis is composed of the neurohypophysis (or posterior lobe) and the adenohypophysis (or anterior lobe). The posterior lobe consists of cells secreting antidiuretic $(\mathrm{ADH})$ or vasopressin and oxytocin, whereas the anterior lobe is composed of five distinct cell types (Table 1). Approximately $50 \%$ of all anterior lobe cells are growth hormone (GH)secreting cells, also known as somatotrophs (Hearney \& Melmed, 2004). GH has a crucial 
role in controlling body growth and metabolism, by acting either directly on multiple tissues or indirectly, via the hepatic production of insulin-like growth factors (mainly IGF-1) (Brook \& Marshall, 2001). Prolactin (PRL)-secreting cells, also known as lactotrophs, in men and nulliparous women may account for approximately $10 \%$ of the anterior pituitary cells, whereas in multiparous women their number can be up to three times higher (Heaney \& Melmed, 2004). PRL inhibits the function of the gonads and stimulates breast enlargement and milk production during pregnancy. GH- and PRL-secreting cells derive from progenitor mammosomatotrophs, which are bi-hormonal cells that can differentiate into either somatotrophs or lactotrophs depending on the needs of each phase the body is in (i.e. growth, or pregnancy and lactation) (Asa \& Ezzat, 2002). Adrenocorticotrophin (ACTH)secreting cells, also known as corticotrophs, account for approximately $10-20 \%$ of all anterior lobe cells (Heaney \& Melmed, 2004). ACTH stimulates the secretion of glucocorticoid hormone (cortisol) from the adrenal gland cortex, while cortisol, in turn, concerts metabolic and anti-inflammatory effects (Goodman, 2003). Apart from ACTH, corticotrophs secrete endorphins, $\gamma$-lipotrophins and other pro-opiomelanocortin derivatives.

Follicle stimulating hormone (FSH) and luteinizing hormone (LH)-secreting cells, or gonadotroph cells, account for roughly equal numbers as corticotrophs (Heaney \& Melmed, 2004). These hormones regulate the sex steroid hormone production in the gonads, as well as the development and maturation of the germ cells. Lastly, a small percentage of thyrotroph cells $(5 \%)$ secrete the thyroid stimulating hormone (TSH) (Heaney \& Melmed, 2004). TSH is the stimulus for thyroid hormone (T3/T4) production from the thyroid gland. Thyroid hormone mainly controls GH synthesis and secretion, metabolism and thermogenesis, as well as foetal skeletal maturation, and central nervous system development and maturation (Goodman, 2003).

\begin{tabular}{|c|c|c|}
\hline Pituitary cells & Secreting hormone & Target tissue \\
\hline Corticotrophs & Adrenocorticotropic hormone (ACTH) & Adrenal gland \\
\hline Gonadotrophs & $\begin{array}{c}\text { Follicle-stimulating hormone (FSH) } \\
\text { and luteinizing hormone }(\mathrm{LH})\end{array}$ & Ovary, Testis \\
\hline Somatotrophs & Growth hormone $(\mathrm{GH})$ & Liver, adipose tissue \\
\hline Lactotrophs & Prolactin & $\begin{array}{c}\text { Ovary, mammary } \\
\text { gland }\end{array}$ \\
\hline Thyrotrophs & Thyroid-stimulating hormone (TSH) & Thyroid gland \\
\hline
\end{tabular}

Table 1. Anterior pituitary cell functions

\section{Origin and development of pituitary adenomas}

Pituitary tumours are believed to develop by monoclonal expansion of a single neoplastic cell, due to an acquired intrinsic primary cell defect (genetic or epigenetic) that confers growth advantage (Asa \& Ezzat, 2002). Indeed, early molecular studies of pituitary tumours, employing X-chromosome inactivation as a means of determining clonality, show that, in most cases, these tumours are monoclonal in origin, suggesting an intrinsic discrete genetic/molecular defect driving the transforming event and perhaps other ones driving progression (Fig. 2). However, these tumours do not follow the sequential classic paradigm apparent in multiple other tumour types, that is, initiation/transformation, hyperplasia, benign adenoma, invasive/aggressive adenoma and, ultimately, carcinoma. Conversely, 
they can arise from a hyper-plastic pituitary tissue, in which there are a number of different clones each with variable potential to develop into a discrete tumour. Consistent with this hypothesis is the finding of different patterns of genetic alterations in recurrent/re-grown tumours compared to primary PA from the same patient (Clayton et al., 2000). Therefore, alongside the monoclonal hypothesis, more recently the polyclonal hypothesis has been proposed. According to it PA originate from the expansion of a single clone coming from a polyclonal hyper-plastic tissue. The initiating stimulus, which might include pituitaryspecific oncogenes, intra-pituitary growth factors, or hypothalamic releasing hormones, would result in hyperplasia of specific cell subtypes in the pituitary giving rise to a number of different clones each one with variable potential to develop into a discrete tumour (Clayton \& Farrell, 2004) (Fig. 2).
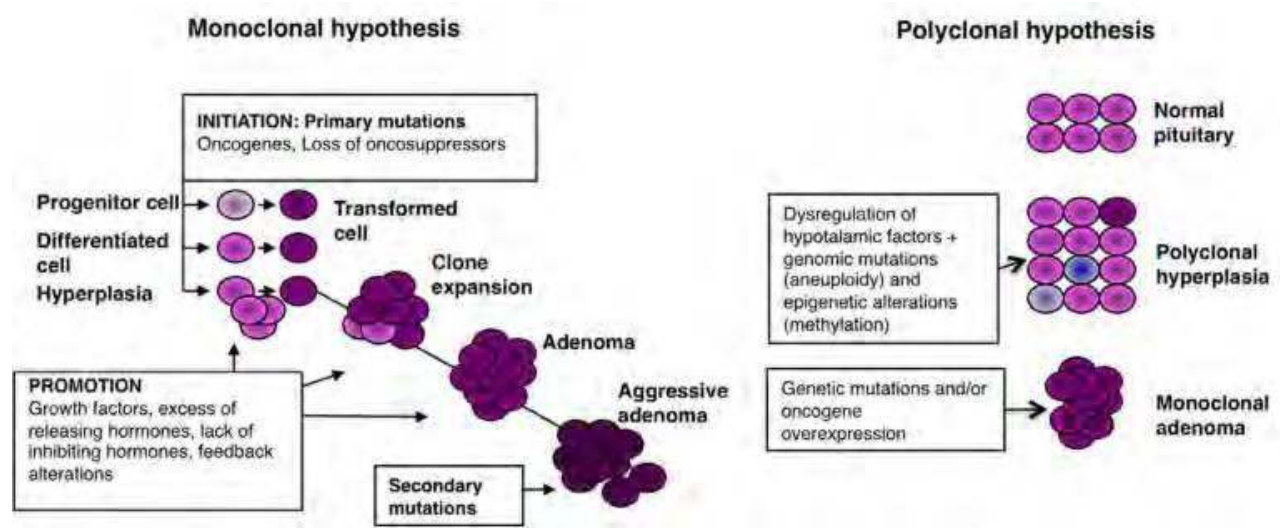

Fig. 2. Schematic representation of the two models of PA genesis (monoclonal and polyclonal hypotheses)

Pituitary tumours are in most of the cases benign and can grow both slowly and expansively. However, although defined as benign, nearly $50 \%$ of PA invade surrounding tissues, but invasiveness rate differs between various PA types (Brook \& Marshall, 2001; Saeger et al., 2007), and mitotic activity is low even in aggressive PA, in contrast to tumours arising from more rapidly replicating tissues (Melmed, 2003). Very rarely PA become metastatic, and are then referred as pituitary carcinomas. Their incidence has been suggested to be $0.2 \%$ of symptomatic pituitary tumours (Pernicone et al., 1997), with almost equal frequency in both sexes (DeLellis et al., 2004; Kaltsas et al., 2005). Most are ACTH- or PRL-secreting tumours (Saeger et al., 2007). The time interval between initial adenoma diagnosis and carcinoma development may vary greatly, depending on the tumour subtype, with a mean of seven years (Pernicone et al., 1997; Sidibe, 2007). The reason of the unique feature of PA to rarely progress to carcinomas has been recently attributed to "premature" senescence-associated molecular pathways activated in PA (Chesnokova \& Melmed, 2010). Premature senescence is a mechanism of irreversible cell cycle arrest and constitutes a strong anti-proliferative response, which can be triggered by DNA damage, chromosomal instability and aneuploidy, loss of tumour suppressive signalling or oncogene activation (Sharpless \& Depinho, 2004). It occurs in benign or early stage tumours, but not in the advanced ones, as a mean to buffer the cell from pro-proliferative signals (Michaloglou et 
al., 2005, as cited in Chesnokova \& Melmed, 2010), and functions to protect against oncogenic transformation, thereby suppressing unscheduled proliferation of damaged and early transformed cells.

\section{Classification and pathogenesis of sporadic pituitary adenomas}

Sporadic PA account for 10-15\% of diagnosed brain tumours and although some differences in their frequencies exist, each of the five hormone-secreting cell types within the gland can give rise to an adenoma (Table 2) (Asa \& Ezzat, 2002; Melmed, 2003). Apart from these adenomas, which are easily diagnosed upon the appearance of the clinical symptomatology consequent to the specific hormone hyper-secreted, micro-adenomas, known as "incidentalomas", are present in $10 \%$ of the general population and are encountered inadvertently by MRI (Melmed \& Kleinberg, 2008). Micro-adenomas are intra-sellar and generally less than $10 \mathrm{~mm}$ in widest diameter. Macro-adenomas, mainly including non functioning pituitary adenomas (NFPA), are greater than $10 \mathrm{~mm}$ and usually impinge upon adjacent sellar structures determining mass effects, including pituitary failure, blindness, headache and various CNS disorders. Immunocytochemistry detects pituitary cell gene products and allows classification of pituitary tumours based on their function (Table 2). With the only exception of the glycoprotein $\alpha$-subunit ( $\alpha$-GSU), immunohistochemical positivity of more than $5 \%$ of cells in the tumour usually reflects peripheral circulating hormone levels (Melmed \& Kleinberg, 2008).

\begin{tabular}{|c|c|c|c|}
\hline Adenoma type & Incidence & $\begin{array}{c}\text { Principal hormone } \\
\text { immunoreactivity }\end{array}$ & $\begin{array}{c}\text { Clinical } \\
\text { manifestation }\end{array}$ \\
\hline Prolactinoma & $29 \%$ & Prolactin & $\begin{array}{c}\text { Hypogonadism, } \\
\text { galactorrhea }\end{array}$ \\
\hline $\begin{array}{c}\text { NFPA } \\
\text { gonadotroph and null- } \\
\text { cell adenoma) }\end{array}$ & $27 \%$ & FSH/LH/ $\alpha$-GSU & Mass effects \\
\hline $\begin{array}{c}\text { Somatotropinoma } \\
\text { Adrenocorticotropinoma }\end{array}$ & $15 \%$ & $\mathrm{GH}$ & $\begin{array}{c}\text { Gigantism or } \\
\text { acromegaly }\end{array}$ \\
\hline $\begin{array}{c}\text { Mixed GH/PRL cell } \\
\text { adenoma }\end{array}$ & $5 \%$ & $\mathrm{GCTH}$ & $\begin{array}{c}\text { Cushing's disease } \\
\text { GH/prolactin }\end{array}$ \\
\hline $\begin{array}{c}\text { Mammogonadism, } \\
\text { acromegaly, } \\
\text { galactorrhea }\end{array}$ \\
\hline adenoma & $1 \%$ & $\mathrm{GH} /$ prolactin & $\begin{array}{c}\text { Hypogonadism, } \\
\text { acromegaly, } \\
\text { galactorrhea }\end{array}$ \\
\hline
\end{tabular}

Table 2. Clinical and pathological characteristics of pituitary adenomas (adapted from Melmed \& Kleinberg, 2008)

A considerable literature details the pathogenic changes occurring in sporadic tumours. However, in marked contrast to most other tumour types, there are few reports that describe genetic mutations (either activating oncogenes or inactivating tumour suppressor genes) that "drive" the inappropriate proliferation of pituitary cells. More often, altered control of 
gene expression, which results in either over-expression or down-regulation of certain proteins, is involved in PA pathogenesis. These proteins include hormones, growth factors, their receptors, the associated signal transduction pathways, cell-cycle regulators and factors involved in chromosomal instability.

\subsection{Gain-of-function mutations}

Oncogenes commonly mutated in the majority of human tumours are very rarely involved in pituitary tumorigenesis. Indeed, apart from GNAS and HMGA2 genes that are mutated in a considerable percentage of GH-secreting adenomas and prolactinomas, respectively, few gain-of-function mutations have been reported in PA.

\subsubsection{GNAS}

Activating $g s p$ mutation is present in up to $40 \%$ of human GH-secreting adenomas (Lyons et al., 1990). They consist in somatic heterozygous point mutations of the $G$ protein $\alpha$-subunit $\left(\mathrm{G}_{\mathrm{s}} \alpha\right)$ gene (GNAS) involving either arginine 201 (replaced with cysteine or histidine) or glutamine 227 (replaced with arginine or leucine) that constitutively activate the $G_{s} \alpha$ protein (Vallar et al., 1987). Similar early post-zygotic somatic mutations in codon 201 of the $G_{s} \alpha$ were identified in tissues derived from patients with McCune-Albright syndrome (MAS), which includes GH-secreting pituitary adenomas (Weinstein et al., 1991). Interestingly, only in the pituitary the $G_{s} \alpha$ expression is mono-allelic - subject to imprinting - and is derived from the maternal allele (Hayward et al., 2001). When expressed in cell lines, mutant $G_{s} \alpha$ showed a 30 -fold decrease in the rate of $\alpha$ subunit-mediated hydrolysis of GTP to GDP, a mechanism required to turn-off its activation (Landis et al., 1989). The resulting G protein activation increases cyclic adenosine mono-phosphate (cAMP) levels and activates protein kinase A (PKA), which in turn phosphorylates the cAMP response element-binding protein (CREB) and leads to sustained constitutive GH secretion and cell proliferation.

The gsp mutations have been identified also in NFPAs and ACTH-secreting adenomas $(<10 \%)$, but quite rarely and not in all the studies (Melmed \& Kleinberg; Lania et al., 2003).

\subsubsection{GNAI2}

Activating gip mutations, involving the GNAI2 gene that encodes a G protein subunit involved in the inhibition of adenylyl ciclase and calcium influx, have been observed in a subset of NFPAs (Williamson et al., 1994). The mutation, observed in 3 out of 22 samples (13\%), consists in an aminoacid substitution that replaces Gln 205 (corresponding to Gln 227 of $G_{s} \alpha$ ) with Arg, which causes activation of Ras (Edamatsu et al., 1998). Interestingly, two tumours with gip mutations also harboured gsp mutations, suggesting the possibility of multiple hits in a stepwise pathogenesis of pituitary neoplasia (Williamson et al., 1994).

\subsubsection{RAS}

The family of RAS genes encodes a 21-kD monomeric GDP/GTP binding protein mainly involved in the transduction of growth factor signalling. These genes may acquire mitogenic properties by point mutations that increase the affinity for GTP in the GTP-binding domain (codons 12 and 13) or prevent GTP-ase activity (codon 61). These mutations are present with high frequency in human neoplasias but are very rare in pituitary tumours (Karga et al., 1992; Cai et al., 1994; Pei et al., 1994, as cited in Lania et al., 2003). Indeed, a Gly12 to Val 
substitution has been observed in one aggressive prolactinoma resistant to dopaminergic inhibition that eventually was lethal. RAS mutations have been also described in metastases of three pituitary carcinomas, but not in the primitive tumours (Lania et al., 2003). Therefore, the rare RAS mutations in pituitary tumours are associated with malignant features, likely representing a late event in pituitary tumorigenesis.

\subsubsection{PKC $\alpha$}

The $\mathrm{Ca}^{2+} /$ calmodulin and phospholipid-dependent protein kinase $\mathrm{C}$ (PKC) is a large ubiquitous kinase family that participates in growth factor- and hormone-mediated signalling and cell proliferation. Point mutations in the gene encoding the PKC $\alpha$ isoform, replacing Gly294 with Asp - a strategic region of PKC containing the calcium-binding site have been observed in four invasive pituitary tumours (Alvaro et al., 1993), causing its overexpression with respect to normal pituitary. These findings were not confirmed by subsequent studies (Schiemann et al., 1997), but ectopic expression of a mutant form of PKC $\alpha$ originally found in human tumours leads to aberrant sub-cellular translocation of the enzyme, together with effects on growth control (Alvaro et al., 1997).

\subsubsection{FGFR4}

The normal pituitary and pituitary tumours produce a wide number of substances with secretory, differentiating, and proliferative potentials and express specific receptors (Lania et al., 2003). The aberrant expression of an N-terminally truncated fibroblast growth factor (FGF) receptor-4, containing the third Ig-like domain, the trans-membrane region and the kinase domain, that is constitutively phosphorylated and causes transformation in vitro and in vivo, has been reported in about $40 \%$ of pituitary adenomas, composed of the various hormone-secreting cell types, but not in normal pituitary. Consistently, the expression of this truncated receptor in lactotroph pituitary cells of transgenic mice results in the development of PA (Ezzat et al., 2002).

\subsubsection{HMGA2}

The HMGA2 protein belongs to the High Mobility Group A (HMGA) family, also including HMGA1, composed of small, non-histone, chromatin-associated proteins that alter the architecture of chromatin and facilitate the assembly of multi-protein complexes of transcriptional factors (Thanos \& Maniatis, 1995). These functions have important rebounds in a wide spectrum of biological processes, ranging from embryonic development, cell differentiation and transformation, cell cycle progression, apoptosis, senescence, DNA repair, up to different aspects of cell physiopathology, including body growth, cardiogenesis, selfrenewal of neural stem cells, inflammation and cancer (Hock et al., 2007; Fedele et al., 2010).

The HMGA2 gene is over-expressed in human prolactinomas (Finelli et al., 2002). Its overexpression is associated, in most of the prolactin-secreting adenomas analised, with gain of chromosome 12 (trisomy/tetrasomy), the most frequent cytogenetic alteration in these tumours, and amplification of the HMGA2 locus (region 12q13-15) or structural rearrangements of chromosome 12 (Finelli et al., 2002).

HMGA2 over-expression was also found in 12 out of 18 NFPA, which rarely harbour trisomy 12 but, differently from what occurs in prolactinomas, HMGA2 up-regulation was associated with amplification and/or rearrangement of the HMGA2 locus in only two cases (Pierantoni et al., 2005). 
It is noteworthy that animal models clearly identified a critical role for HMGA genes in pituitary tumorigenesis since, as more deeply described below, transgenic mice overexpressing either the Hmga1 or the Hmga2 genes develop mixed prolactin/GH-secreting adenomas with a high penetrance (Fedele et al., 2002; 2005).

\subsection{Loss-of-function mutations}

Aberrant pituitary cell proliferation may result from the inactivation of either common tumour suppressor genes (TSGs) or specific inhibitors of pituitary cell function and growth. Unlike oncogenes that drive neoplastic transformation also when mutated in heterozygosity, TSGs are usually recessive and the inactivation of both alleles is required to cause the loss of anti-tumoral action.

Even though the key role of some TSGs (p27kip1, RB) in pituitary tumorigenesis has been clearly demonstrated in mice (Fero et al., 1996; Jacks et al., 1992, as cited in Fedele \& Fusco, 2010), they are not or very rarely mutated in human PA.

Low expression levels of p27Kip1 protein have been found in ACTH-secreting adenomas, recurrent PA, and pituitary carcinomas by immunohistochemistry. However, as it occurs in other human neoplasias, no changes in p27kip1 mRNA levels were observed, suggesting the involvement of post-translational mechanisms accounting for the impairment of p27kip1 protein stabilization in these tumours (Dahia et al., 1998).

Recently, reduced $\mathrm{p} 2{ }^{\text {kip } 1}$ protein levels were found in a NFPA harbouring a novel mutation of DKC1, encoding for dyskerin, a pseudouridine synthase that modifies rRNA and regulates telomerase activity. This mutation, consisting in a specific aminoacid substitution (S485G), significantly alters DKC1 stability/pseudouridylation activity (Bellodi et al., 2010). However, the link between DKC1 mutation and p27kip1 expression is not clear yet.

Loss of heterozygosity ( $\mathrm{LOH}$ ) on chromosome 13q14, where $R B$ is located, is a relatively frequent event. In particular, deletion of one $R B$ allele is observed in most highly invasive or malignant pituitary tumours and their metastases. The retained allele is not mutated but, as better described below, it is frequently hyper-methylated (Pei et al., 1995; Simpson et al., 1999; 2000, as cited in Lania et al., 2003). However, the presence of cases of LOH at 13q14 in PA in the absence of mutation or hyper-methylation of the $R B$ allele may suggest the involvement in PA of another still unknown TSG located in the same chromosomal region (Bates et al., 1997, as cited in Vandeva et al., 2010).

MEN1 gene mutations, responsible for the MEN-1 syndrome (fully described in paragraph 5.1 ), are uncommon in sporadic PA ( 3\%), even in the presence of LOH of 11q13 (Melmed \& Kleinberg). Indeed, just four cases have been described: in one NFPA, in one ACTHsecreting adenoma (Zhuang et al., 1997), in one prolactinoma (Wembin et al., 1999) and in one TSH-secreting adenoma (Schmidt et al., 1999), suggesting, also in this case, the presence of another adenoma-relevant TSG on chromosome 11.

More recently, the aryl hydrocarbon receptor interacting protein $(A I P)$ gene, also located on chromosome 11q13 and responsible for familial isolated pituitary adenomas (fully described in paragraph 5.4), has been found to be mutated in about 3\% of sporadic GH-secreting adenoma (Occhi et al., 2010). The AIP protein is a co-chaperone and though to be important in keeping proteins and protein complexes in functional formation. It interacts with several protein partners, including hydrocarbon receptor, phosphodiesterases, survivin, G proteins and RET, and currently it is uncertain which of them plays a key role in pituitary tumorigenesis. The AIP mutation types identified in sporadic PA include nonsense, splice 
site substitutions, missense, frameshift and in-frame deletions. Some of them have been only identified in sporadic PA, whereas some others have been identified in both familial and sporadic cases (Ozfirat \& Korbonits, 2010).

Interestingly, no mutations in the TP53 gene have been found in PA, even though they have been detected in more than $50 \%$ of all human cancers, including tumours of the central nervous system (Lania et al., 2003). Since TP53 mutations are associated with tumour progression, this result appears consistent with the intrinsic nature of pituitary tumour evolution, which rarely progress to carcinoma.

\begin{tabular}{|c|c|c|}
\hline Pituitary tumour type & Mutated gene & Incidence \\
\hline $\begin{array}{c}\text { GH-secreting } \\
\text { NFPA/ACTH-secreting }\end{array}$ & GNAS & $\begin{array}{c}40 \% \\
<10 \%\end{array}$ \\
\hline NFPA & GNAI2 & $13 \%$ \\
\hline Pituitary carcinomas/invasive prolactinomas & $R A S$ & rare \\
\hline Invasive NFPA & $P K C \alpha$ & rare \\
\hline All types & FGFR4 & $\sim 40 \%$ \\
\hline $\begin{array}{l}\text { Prolactinomas } \\
\text { NFPA }\end{array}$ & HMGA2 & $\begin{array}{l}\sim 80 \% \\
\sim 10 \% \\
\end{array}$ \\
\hline $\begin{array}{l}\text { NFPA, ACTH-secreting, prolactinoma, TSH- } \\
\text { secreting }\end{array}$ & MEN1 & $\sim 3 \%$ \\
\hline GH-secreting & AIP & $\sim 3 \%$ \\
\hline NFPA & DKC1 & rare \\
\hline
\end{tabular}

Table 3. Summary of gene mutations and their incidence in sporadic pituitary adenomas.

\subsection{Gene over-expression}

To identify novel factors involved in pituitary tumour pathogenesis, several studies have been focused on differences in gene expression between PA and normal pituitary tissue. Indeed, more frequently than gene mutations, alterations of gene expression have been reported in human PA. They include both gene over-expression and down-regulation, the latter being mainly associated with epigenetic gene silencing.

\subsubsection{Cyclins}

Cell cycle dysregulation is the main pathogenetic event in the development of pituitary tumors. In fact, it has been estimated that more than $80 \%$ of human pituitary tumours display alterations at least in one of the regulators of the G1/S transition of the cell cycle (Malumbres \& Barbacid, 2001, as cited in Fedele \& Fusco, 2010). In particular, overexpression of different cyclins has been reported in various functioning and non functioning PA.

Cyclin E expression is increased in ACTH adenomas compared to normal pituitary tissue (Jordan et al., 2000, as cited by Fedele \& Fusco, 2010), likely related to the low levels of nuclear p27kip1 in these tumours (Musat et al., 2010).

Cyclin D1, as well as cyclin D3, is over-expressed in aggressive NFPA (Jordan et al., 2000, Turner et al., 2000, Saeger et al., 2001, Simpson et al., 2001, as cited in Fedele \& Fusco, 2010). One of the possible mechanisms responsible of such over-expression could be the activation of the Wnt- $\beta$-catenin pathway that targets cyclin D1. Indeed, transfecting GH3 pituitary cells 
with Wnt inhibitory factor-1 (WIF1) decreased cell proliferation and colony formation, suggesting an involvement of Wnt pathway in pituitary tumorigenesis (Elston et al., as cited in Musat et al., 2010). Moreover, cyclin D1 gene allelic imbalance has been described in about 25\% of analysed adenomas (Hibberts et al.,1999, as cited in Fedele \& Fusco, 2010).

B-type cyclins have recently been found over-expressed in many human pituitary adenomas, with prevalence in prolactinomas (Wierinckx et al., 2007; De Martino et al., 2009).

\subsubsection{PTTG}

Pituitary tumour transforming gene (PTTG) was isolated from experimental pituitary tumours by mRNA differential display PCR between rat pituitary tumor cells and normal pituitary tissue (Pei \& Melmed, 1997). Subsequent experiments showed its abundant expression in nearly all pituitary tumour types, especially prolactinomas, but not in normal pituitary (Zhang et al., 1999).

PTTG codes for securin that interacts and inhibits the proteolitic protein separase, which degrades the cohesin complex involved in holding together replicated paired sister chromatids during metaphase, leading, when over-expressed, to cell aneuploidy, which is frequently observed in PA (Uhlmann et al., 1999; Zou et al., 1999, as cyted by Fedele \& Fusco, 2010). In addition, PTTG also induces FGF production and angiogenesis and is upregulated by oestrogen (Melmed \& Kleinberg, 2008) and modulates the G1/S phase transition by interacting with Sp1 and regulating the transcriptional activity of the cyclin D3 promoter (Tong et al., 2007, as cyted by Fedele \& Fusco, 2010). Interestingly, PTTG is regulated by CDK1-mediated phosphorylation suggesting a link between the control of the cell cycle by CDKs and securin function (Holt et al., 2008, as cyted by Fedele \& Fusco, 2010). Finally, PTTG has been implicated in the premature senescence that typically characterizes PA and that is responsible for the benign nature of this tumour (see paragraph 3). Indeed, both PTTG deletion and over-expression cause extensive pituitary cell aneuploidy, which causes intracellular p53 accumulation and p21 induction, resulting in senescence (Chesnokova \& Melmed, 2010). Therefore, high PTTG levels in PA may initially mediate excessive proliferation, and lead to defective DNA replication and aneuploidy. Activation of pituitary DNA damage pathways triggers p21, a barrier to tumour growth, which in turn may restrain further growth and malignant transformation (Chesnokova \& Melmed, 2010).

\subsubsection{HMGA1 and HMGA2}

Both HMGA1 and HMGA2 genes are over-expressed in different subtypes of PA, with the highest levels in prolactin- and/or GH-secreting tumours, compared to normal pituitary (De Martino et al., 2009). In addition, HMGA1 expression is significantly higher in invasive adenomas or macro-adenomas than in non-invasive adenomas or micro-adenomas and shows the highest level in grade IV, more aggressive pituitary adenomas, than in grades I, II and III (Wang et al., 2010). However, while HMGA2 over-expression is associated to gene amplification (see paragraph 4.1.6), HMGA1 over-expression does not appear to depend upon cytogenetic alterations involving the 6p21 chromosomal region, where the HMGA1 gene is located (Fedele et al., 2010).

Studies in mice over-expressing either Hmga1 or Hmga2 gene under the transcriptional control of the cytomegalovirus promoter, clearly demonstrated the causal role of both these genes in pituitary tumorigenesis. Indeed, both these transgenic mouse models, with different incidence and latency period, develop mixed GH/PRL-secreting PA (Fedele et al., 
2002; 2005). The mechanism by which HMGA proteins induce the onset of PA mainly involves the interaction with $\mathrm{pRB}$, which causes the displacement of HDAC1 from the pRB/E2F1 complex, and the resulting enhancement of E2F1 activity (Fedele et al., 2006). The crucial role of the HMGA-mediated E2F1 activation in pituitary tumorigenesis was confirmed by crossing Hmga2-overexpressing with E2f1-knockout mice, which resulted in the suppression of pituitary tumorigenesis in double mutant mice (Fedele et al., 2006). The analysis of the expression profile of pituitary adenomas developed by Hmga transgenic mice in comparison with normal pituitary from wild-type mice led to the identification of other genes potentially down-stream in the molecular pathway leading to PA onset in Hmga transgenic mice (De Martino et al., 2007; 2009). Among these genes, Mia/Cd-rap, coding for a secreted product of malignant melanoma cells, and Ccnb2, encoding the cyclin B2, which plays an important role in cell cycle progression, are directly regulated, by the HMGA proteins at transcriptional level (De Martino et al., 2007; 2009). Consistent with these data, the MIA gene, which is down-regulated by HMGA proteins, is down-regulated in human prolactinomas compared to normal pituitary (Evans et al., 2008), and the CCNB2 gene, which is up-regulated by HMGAs, is over-expressed in PA versus normal pituitary, in statistically significant association with HMGA expression (De Martino et al., 2009).

\subsubsection{Galectin 3}

Recent evidences suggest that galectin-3 (Gal-3), a member of a phylogenetically conserved family of lectins sharing a consensus sequence of about 130 amino acids and a carbohydraterecognition domain responsible for $\beta$-galactosides binding, plays an important role in pituitary progression (Righi et al., 2010). Gal-3, encoded by the LGALS3 gene on chromosome 14q21-22, is ubiquitously expressed mainly in the cytosol, but it can easily traverse the intracellular and plasma membranes. Extracellular Gal-3 mediates cell migration, cell adhesion, and cell-to-cell interactions, whereas intracellular Gal-3 inhibits apoptosis and is up-regulated during neoplastic progression and metastasis in several human cancer (Righi et al., 2010). In different studies, Gal-3 expression was reported in folliculo-stellate cells and in normal and neoplastic pituitary prolactin- and ACTH-secreting cells, with a significantly higher presence in carcinomas versus adenomas (Riss et al., 2003; Ruebel et al., 2006, as cited in Righi et al., 2010). Indeed, down-regulation of Gal-3 , by RNA interference induced a significant decrease in cell proliferation and an important increase in apoptosis of pituitary HP75 cells (Riss et al., 2003, as cited in Righi et al., 2010), indicating a causal role of Gal-3 expression in pituitary tumorigenesis.

Recent studies suggest that the consequences of Gal-3 over-expression in pituitary carcinoma development could be related to changes in the expression levels of cell cycle targets of the Wnt/ $\beta$-catenin signalling pathway, such as cyclin D1 and the proto-oncogene c-myc (Kim et al., 1999; Lin et al., 2000; Shimura et al., 2004, as cited in Righi et al., 2010).

\subsection{Gene down-regulation and epigenetic gene silencing}

For many of the genes whose expression is lost or drastically reduced in PA versus normal pituitary, the epigenetic gene silencing is the common mechanism .

The term epigenetic refers to a process that heritably influences the expression of a gene without genetic change to the underlying DNA sequence itself (Jaenish \& Bird, 2003). The silencing of TSGs, through or associated with CpG island methylation, is recognized as a major mechanism of gene inactivation that frequently coexists with genetic lesions in most 
cancers studied to date (Esteller, 2007). It has been proposed that methylation silences gene expression by hindering the access of transcription factors to their binding sites. Additionally, it is proposed that silencing might be achieved by methyl-binding proteins that recruit chromatin-modifying factors that compact and inactivate the chromatin (Tateno et al., 2010). The epigenetic events involved in pituitary tumorigenesis that lead to downregulation of gene and/or protein expression are mainly due to promoter hypermethylation and/or microRNA (miRNA)-dependent impairment of protein translation.

In the following subsections we will describe the main genes down-regulated by promoter methylation in PA compared to normal pituitary tissue.

\subsubsection{Cell cycle inhibitors}

The retinoblastoma (pRB) family members are the main inhibitors of cell cycle progression from G1 to $S$ phase. Even though heterozygous pRb-knockout mice develop PA, no mutations at the $R B$ gene have been so far found in human pituitary tumours. However, lack of expression of $\mathrm{pRB}$ has been found in a small number of pituitary tumours where the promoter region of $R B$ is hyper-methylated (Simpson et al., 2000).

Hyper-methylation of the promoter region also accounts for the loss of p16INK4 protein expression, which is relatively frequent in PA (Simpson et al., 1999). $R B$ and p16 INK4a methylations tended to be mutually exclusive (Yoshino et al., 2007).

As for $\mathrm{pRB}$ and p16 $6^{\mathrm{INK} 4 a}$, down-regulation of p21 Cip1 and p27kip1 in pituitary adenomas may also be due to epigenetic modifications, including DNA and/or histone methylation (Yoshino et al., 2007, Zhu et al., 2008).

\subsubsection{Hypotalamic hormone receptors}

Somatostatin (SS) and dopamine (DA) are among the key regulators of hormone secretion by the anterior pituitary gland. SS mediates its inhibitory activity on pituitary hormone secretion via specific seven trans-membrane G-protein coupled SS receptors (sst). Human adult pituitary tissue expresses sst1, sst2, sst3 and sst5. Similarly, DA action is mediated by five receptors, named D1, D2, D3, D4 and D5, being D2 the only one highly expressed in pituitary cells (lactotroph and non-lactotroph). DA and SS receptors can form heterodimers that may have influence on ligand binding, signalling and internalization of the respective receptors (Hofland et al., 2010).

The expression of sst subtypes in human PA is different in comparison with pituitary and from tumour to tumour. GH-secreting adenomas display a predominant expression of sst2 and sst5, whereas a subset of GH-secreting adenomas expresses sst1 and sst3 as well. In prolactinomas, sst 1 and sst 5 are the predominantly expressed ssts, whereas sst 2 is expressed at a detectable level in only a minority of them. ACTH-secreting adenomas express sst5 at highest level, and most of them co-express sst 2 at low level. Silent corticotroph adenomas display considerable higher sst1 and sst2, but lower sst5 expression, compared with ACTH-secreting PA. NFPA mainly express sst3 and to a lesser degree sst2. In TSH-secreting PA, sst2 is mainly expressed, with co-expression of sst 3 and sst5 in a subset. Finally, two novel truncated isoforms of sst5 (sst5MD5 and sst5MD4) with five and four trans-membrane domains, respectively, have been identified in PA. In particular, sst5MD4 was found in $85 \%$ of GH-secreting adenomas and its expression was negatively associated with the inhibitory effect of octreotide on circulating GH levels in vivo (Hofland et al., 2010). 
The differential expression of specific sst subtypes in PA may be caused by epigenetic events. Indeed, it has been recently identified an upstream promoter of the human somatostatin receptor, hSSTR2, which is controlled by epigenetic modifications, including DNA methylation and histone acetylation (Torrisani et al., 2008).

As far as DA receptor expression, mainly D2 has been demonstrated in the majority of PA, although expression levels may vary among adenomas. Interestingly, the loss of D2 expression correlates with increased $\mathrm{CpG}$ island-associated methylation and enrichment for histone H3K27me3. Conversely, D2 expression is associated to enrichment for H3K9Ac and barely detectable H3K27me3 (Al-Azzawi et al., 2011).

Therefore, a combined treatment with epigenetic drugs and DA agonists for the medical management of different pituitary tumour subtypes, resistant to conventional therapies, could be envisaged.

\subsubsection{GADD45 $\gamma$}

One of the growth inhibitory genes whose expression is lost in the majority of human PA is GADD45 $\gamma$, a p53-regulated gene involved in inhibition of cell growth. Indeed, it was found abundantly expressed in normal pituitary and strongly down-regulated in different PA subtypes. Moreover, suppression of cell proliferation was observed when GADD45 $\gamma$ was expressed in pituitary cell lines (as reviewed by Zhang et al., 2010), suggesting a causal role of its loss in pituitary tumorigenesis. The loss of GADD45 $\gamma$ expression in pituitary tumour cells has been associated with methylation of the GADD $45 \gamma \mathrm{CpG}$ island, frequently (58\%) reported in PA not expressing the GADD45 $\gamma$ gene (Bahar et al., 2004).

\subsubsection{MEG3}

The Maternally Expressed Gene 3 (MEG3), a large maternal imprinted non-coding RNA gene located on chromosome $14 \mathrm{q} 32$, is highly expressed in the pituitary but specifically absent in gonadotroph-derived NFPA (Zhang et al., 2010). No gene deletion or mutation at the MEG3 gene was found in such tumours, but increased DNA methylation in promoter and enhancer regions, responsible for loss of MEG3 expression, was identified in tumours in comparison with normal pituitary (Zhao et al., 2005).

MEG3 is able to suppress proliferation of different types of human tumour cells due to its ability to act up-stream of two well known TSGs, such as p53 and pRB. Indeed, MEG3 stimulates p53-mediated transcriptional activation of specific targets, such as GDF15, a TGF$\beta$ family member with an anti-proliferative activity, and leads to the accumulation of p53 protein levels. However, it can also suppress cell proliferation in the absence of p53 through a pRB-dependent mechanism (Zhou et al., 2007, as cited in Zhang et al., 2010).

\subsubsection{ZAC1}

The zinc-finger protein $\mathrm{ZAC1}$ is a transcription factor and co-regulator that plays a key role in pituitary development, maturation and tumorigenesis. Indeed, it lies downstream to the mitogenic MAPK and survival PI3K pathways, and its target genes control cell proliferation and hormone synthesis of pituitary cells (Theodoropoulou et al., 2010). As co-regulator, ZAC1 is involved in the activation of different members of the nuclear receptor and p53 family (Huang \& Stallcup, 2000; Huang et al., 2001, as cited in Theodoropoulou et al., 2010), which are key regulators of cell growth, differentiation, homeostasis and development. In particular, through activation of p53, ZAC1 induces the cell-cycle inhibitor p21Cip1 causing 
growth arrest. Moreover, ZAC1 can also directly bind to the proximal promoter of p21Cip1 and confer trans-activation to the GC-rich Sp1-responsive elements (Huang et al., 2007, as cited in Theodoropoulou et al., 2010).

ZAC1 is highly expressed in all types of hormone-producing pituitary cells (Pagotto et al., 2000, as cited in Theodoropoulou et al., 2010). The chromosomal region where it maps (6q24-25) is frequently deleted in solid tumours, and LOH at least at one informative marker has been reported in $50 \%$ of pituitary adenomas analysed, but no mutations in the ZAC1 coding region have been found (Pagotto et al. 2000, as cited in Theodoropoulou et al., 2010). However, ZAC1 mRNA and protein levels were found reduced in all types of PA, especially in null cell NFPA, where ZAC1 expression may be completely absent, suggesting a putative role of ZAC1 in pituitary differentiation, since null cell adenomas are thought to be dedifferentiated tumours (Theodoropoulou et al., 2010).

It is likely that the loss of ZAC1 expression may be due to an aberrant methylation of a $5^{\prime}$ CpG island in the ZAC1/LOT1 gene, since it has been reported that this region is differentially methylated in ovarian and breast cancer compared to normal tissues (Abdollahi et al., 2003). Moreover, histone deacetylation, elicited by a mechanism up-stream of the LOT1 gene, has been suggested as an additional epigenetic modification that controls ZAC1 expression (Abdollahi et al., 2003).

\section{5 microRNA expression in pituitary adenomas}

MicroRNAs (miRNAs/miRs) are a huge class of non-coding small RNAs that posttranscriptionally regulate gene expression by targeting the $3^{\prime}$ un-translated mRNA regions. miRNAs control a wide range of biological functions, including cell proliferation, differentiation, apoptosis and metabolism, and are involved in human pathology, including cancer (Bartel, 2004). Indeed, it has been suggested that some miRNAs might have oncogenic or tumour suppressor functions, playing key roles in tumorigenesis (Croce, 2009). In PA of different histotypes, a significant down-regulation of miR-15a and miR-16-1, that inversely correlates with tumour diameter and directly correlates with the secretion of the anti-neoplastic cytokine $\mathrm{p} 43$, has been shown in comparison with normal pituitary (Bottoni et al., 2005).

The analysis of the differential expression profile of PA of specific histotypes in comparison with normal pituitary, has identified several other miRNAs potentially involved in pituitary tumorigenesis (Bottoni et al., 2007; Amaral et al., 2009; Mao et al., 2010). In ACTH-secreting adenomas six more miRNAs (miR-145, miR-21, miR-141, let-7a, miR-150 and miR-143), other than miR-15a and miR-16, have been shown to be down-regulated (Amaral et al., 2009). In GH-secreting adenomas 52 miRNAs have been reported to be differentially expressed (23 up-regulated and 29 down-regulated). Nine of them are differentially expressed between micro- and macro-adenomas (Mao et al., 2010). Also in NFPAs, six miRNA, including miR140, miR-99b, miR-99a, miR-30c, miR-30b and miR-138-2, (the first five up-regulated and the last one down-regulated) are differentially expressed in macro- versus micro-adenomas (Bottoni et al., 2007).

Interestingly, most of the identified miRNAs differentially expressed in PA versus normal pituitary tissue are involved in cell growth, apoptosis, cell proliferation and tumour development. In particular, miR-126 and miR-381, both down-regulated in somatotropinomas, target PTTG (Mao et al., 2010). Furthermore, recent studies have demonstrated that the down-regulation of five miRNAs (let-7, miR-15, miR-16, miR-26 and 
miR-196a-2), able to target the HMGA proteins, plays a key role in pituitary tumorigenesis (De Martino et al., 2009b; Kaddar et al., 2009; Quian et al., 2009; Palmieri et al., manuscript in preparation, as cited in Fedele et al., 2010).

Therefore, an innovative therapeutic approach for PA could be the use of miRNAs able to target proteins playing key role in pituitary tumorigenesis and whose expression is downregulated in PA. Indeed, such approach has been suggested for PA resistant to classical PA therapies, in which the resistance to SS and DA agonists is associated to different miRNA expression (Bottoni et al., 2007; Mao et al., 2010).

\section{Familial pituitary adenomas}

The vast majority of pituitary adenomas occur spontaneously, which means that they are not inherited, while familial pituitary tumours account for approximately $5 \%$ of all pituitary adenomas (Marx \& Simonds, 2005). These tumours arise as a component of endocrinerelated tumour syndromes, namely Multiple Endocrine Neoplasia type I (MEN1), Multiple Endocrine Neoplasia type IV (MEN4) and Carney complex (CNC), or, if the condition seems to affect only the pituitary gland, as Familial Isolated Pituitary Adenomas (FIPA).

Different gene mutations have been identified in patients affected by familial pituitary adenomas. In highly penetrant conditions, affected individuals manifest the disease phenotype at a considerably younger age (on average 4 years) than their sporadic counterparts; this is due to the shorter time elapse before a "second hit" occurs in a predisposed tissue that already harbours a germline genetic defect. On the contrary, lowpenetrance alleles may be more common in the general population, since the presence of a predisposing allele does not necessarily cause a disease-associated phenotype, or it may be associated with age-related penetrance and gender-specific risks (Fearon, 1997; Nagy et al., 2004).

\subsection{Multiple Endocrine Neoplasia type I (MEN1)}

MEN1 is an inherited autosomal dominant disorder that causes tumours in various endocrine glands (Brandi et al., 2001). MEN1 is sometimes called multiple endocrine adenomatosis or Wermer's syndrome, after one of the first doctor recognised and described it. MEN1 is rare, occurring in about one in 30,000 people. The disorder affects both sexes equally and shows no geographical, racial, or ethnic preferences (Teh et al., 1998).

The gene causing MEN1, identified in 1997, was located on chromosome 11q13, and consists of 10 exons that encode a 610-amino acid protein referred to as Menin (Teh et al., 2005). Menin is predominantly a nuclear protein that has roles in transcriptional regulation, genome stability, cell division and proliferation (Marx \& Simonds, 2005). Thus, in transcriptional regulation, Menin interacts with the activating protein-1 (AP-1) transcription factors JunD and C-Jun, and members of the NF-kB family transcriptional regulators, to repress transcriptional activation; members of the Smad family, to inhibit the transforming growth factor- $\beta$ (TGF- $\beta$ ) and the bone morphogenetic protein-2 (BMP-2) signalling pathways. A wider role in transcription regulation has also been suggested, as Menin has been shown to be an integral component of histone methyltransferase complexes (Agarval et al., 2004).

MEN1 tumours frequently have LOH of the MEN1 locus, which is consistent with a tumour suppressor role of MEN1. Also mutations of the MEN1 gene have been identified, and, to 
date, about 1300 mutations have been reported: approximately $23 \%$ are nonsense mutations, around $41 \%$ are frameshift deletions or insertions, $6 \%$ are in-frame deletions or insertions, $9 \%$ are splice-site mutations, $20 \%$ are missense mutations, and $1 \%$ are whole or particular gene deletions. The majority $(>70 \%)$ of these mutations are predicted to lead to truncated forms of Menin disrupting the interactions of Menin with other proteins and altering critical events in cell cycle regulation and proliferation. However, a comparison of the clinical features in patients and their families with the same mutations reveals an absence of phenotype-genotype correlations (Lemos \& Thakker, 2008).

In patients with MEN1, several endocrine glands form tumours and become hormonally overactive (Brandi et al., 2001). In MEN1, the overactive glands most often include the parathyroid glands, the pancreas and the pituitary. The parathyroids are the endocrine glands earliest and most often affected by MEN1. In MEN1 patients, all four parathyroid glands tend to be overactive, causing hyperparathyroidism. The parathyroid glands form tumours that release too much PTH, leading to hyper-calcemia. People with MEN1 have about a 20 to 60 percent chance of developing gastrinomas. Gastrin is a hormone that stimulates secretion of gastric acid $(\mathrm{HCl})$ by the parietal cells of the stomach and aids in gastric motility. The pituitary gland develops a tumour in about one in four people with MEN1. This tumour most often releases too much prolactin, developing a prolactinoma. High prolactin levels can cause excessive production of breast milk or interfere with fertility in women or with sex drive and fertility in men. Other pituitary tumour types in MEN1 can be NFPA or GH-secreting adenoma.

\subsection{The novel Multiple Endocrine Neoplasia type IV (MEN4) syndrome}

Recently, it has been recognized a new rare type MEN1-like syndrome named Multiple Endocrine Neoplasia type 4 (MEN4) caused by mutation of CDKN1B (Pellegata et al., 2006). This gene, which maps at 12p13 locus, codes for the 196 amino acid cyclin-dependent kinase inhibitor p27kip1. CDKN1B/p27Kip1 protein plays an important role in the cell cycle regulation, through the binding and inhibition of cyclin/CDK complexes during the cellular G1 to S phase transition (Sherr \& Roberts, 1999); thus, CDKN1B/p27Kip1 participates in determining several cell fate decisions, including proliferation, differentiation, apoptosis, cell density, and even cell migration (Besson et al., 2004; Chu et al., 2008). The CDKN1B changes so far identified in MEN4 patients either affect the localization, the stability or the protein binding abilities of p27kip1. Interestingly, it has been shown that $C D K N 1 B$ is a transcriptional gene target of Menin (Karnik et al., 2005). These findings point to a critical role for p27-mediated cell cycle regulation in neuroendocrine cell homeostasis.

Six germline mutations have been identified so far. Two of them determine a truncated protein with an aberrant cytoplasmic localization. Other two mutations are located in p27kip1 region involved in the binding to Grb2 or CDK2. Another one is in the p27kip1 regulatory region at -7 position of the Kozak sequence, and is associated with reduction in p27kip1 protein levels. Lastly, a mutation at stop codon to $Q$, coding for an aberrant longer p27kip1 including 60 aa more in comparison with the wild-type protein, has been recently identified (Molatore \& Pellegata, 2010). Bi-allelic inactivation of CDKN1B is an exceedingly rare condition in human tumours, which usually exhibit hemizygous loss of the locus. Therefore, the finding that tumours in $C D K N 1 B$ mutation carriers show loss of heterozygosity or lack of $\mathrm{p} 2 \mathrm{k}^{\mathrm{kip} 1}$ expression suggests that $\mathrm{p} 2 \mathrm{k}^{\mathrm{kip} 1}$ may behave as a 'canonical' tumour suppressor in neuroendocrine cells. 
The phenotypic features associated with MEN4 are still undefined due to the small number of patients reported so far. It is worth noting that these families do not exhibit significant phenotypic differences when compared to MEN1 mutation-positive families (Bassett et al., 1998).

\subsection{Carney complex (CNC)}

Carney complex is a hereditary condition. It is associated with spotty skin pigmentation, myxomas (benign or non cancerous connective tissue tumours), and benign or cancerous tumours of the endocrine glands such as the adrenal (Cushing's syndrome), thyroid and pituitary gland (GH-secreting tumours). Although people with Carney complex have an increased risk of cancer, most tumours are benign.

About $60 \%$ of people with Carney complex have a mutation in the CNC1 locus, which maps on chromosome 17q24 (Stratakis et al., 1996). This locus was found to harbour the predisposing gene protein kinase A type I-alpha regulatory subunit (PRKAR1A), encoding a serine/threonine protein kinase A (PKA) regulatory subunit that is the main mediator in cAMP signalling. The function of PRKAR1A is to bind cAMP and regulate the function of the catalytic subunits of the protein kinase A (PKA) holoenzyme. Inactivating PRKAR1A mutations have been identified in up to $60 \%$ of CNC patients meeting the diagnostic criteria (Kirschner et al., 2000). Almost all 40 distinct germline PRKAR1A mutations reported so far lead to mRNA instability, abnormal PRKAR1A and increased PKA activity with elevated cAMP levels in the affected tissues (Groussin et al., 2002), leading to typical manifestations of CNC. However, it is likely that other genes may be associated with Carney complex. Indeed, many of CNC tumours show amplification or deletion of the $2 \mathrm{p} 16$ region (the CNC2 locus) (Matyakhina et al., 2003).

Carney complex follows an autosomal dominant inheritance pattern, in which a mutation happens in only one copy of the gene. It is estimated that between $50 \%$ and $70 \%$ of cases of Carney complex are familial, while the remaining $30 \%$ to $50 \%$ of cases result from new mutations.

\subsection{Familial Isolated Pituitary Adenomas (FIPA)}

Recently, a distinct clinical entity, namely Familial Isolated Pituitary Adenomas (FIPA), has been reported. It characterizes families with isolated pituitary adenomas outside the clinical and genetic contexts of MEN1 and CNC (Daly et al., 2005).

The pituitary tumour types occurring in these families are most commonly GH-secreting adenomas (causing acromegaly or acromegalic gigantism), prolactinomas or NFPA, very rarely ACTH-secreting adenomas (causing Cushing's disease) or TSH-secreting adenomas (Daly et al., 2006). The disease most often starts in adulthood, very rarely in childhood.

The gene responsible for this familial disease has been identified in only $20 \%$ of the families. It is called Aryl hydrocarbon receptor (AHR) Interacting Protein, in short AIP, which is part of AHR pathway (Daly et al., 2007). AIP gene is located on chromosome 11q13, and its product is a member of the immonophilin family of proteins with three tetraicopeptide repeats, the TPR domains, that act as scaffolds for the assembly of different multi-protein complexes. AHR is a ligand-inducible transcription factor that mediates the cellular response to xenobiotic compounds. Upon ligand binding, AHR is activated by a conformation change that exposes a nuclear localization signal: the receptor translocates to the nucleus, where it binds to aryl hydrocarbon receptor nuclear translocator. The 
heterodimer binds to the xenobiotic response element and regulates gene expression. Loss of heterozygosity of AIP gene has been found in tumours of FIPA patients. According to the Knudson two-hit hypothesis, the first hit is due to an inherited germline mutation of one allele and the second hit is a somatic deletion of the other allele (Knudson, 2001).

Almost 50 different germline AIP mutations have been demonstrated in the setting of FIPA. Most of them are present in the TPR domain. Other nonsense and missense mutations all along the coding sequence have been described (Beckers \& Daly, 2007). The appearance of PA occurs earlier in the patients carrying AIP mutations with respect to the AIP negative patients. In FIPA families with normal AIP, a linkage with loci 2p16, 3q28, 4q32.3-4q33, 8q12.1, 19q13.4, and 21q22.1 has been shown, suggesting that mutations in several other genes may be involved in the development of FIPA syndrome (Toledo et al., 2010).

\begin{tabular}{|c|c|c|c|}
\hline Adenoma type & Incidence & Mutated gene & Syndrome \\
\hline $\begin{array}{c}\text { GH-secreting } \\
\text { PRL-secreting }\end{array}$ & $10 \%$ & MEN1 & $\begin{array}{c}\text { Multiple endocrine } \\
\text { neoplasia type 1 } \\
\text { NFPA }\end{array}$ \\
(MEN1)
\end{tabular}

Table 4. Familial pituitary adenomas.

\section{Conclusions}

Based on all the events associated with the pathogenesis of PA, the sequence of genetic alterations likely begins, at least for GH-secreting adenomas, with an aberrant cAMP signalling that causes polyclonal hyperplasia and/or initial adenoma formation (as evidenced by GNAS and PRKAR1A involvement). Then, for all subtypes, growth of a monoclonal pituitary tumour is initiated and/or assisted by cell-cycle dysregulation and aneuploidy. Menin down-regulation, methylation of certain target genes, aneuploidy and/or disruption of genomic integrity in a greater scale lead to a well-growing pituitary adenoma, but still responsive to medical and/or surgical treatment (depending on the type). Finally, E2F1 activation, cell cycle dysregulation, PTTG over-expression and/or additional growth factor up-regulation and increased angiogenesis lead to aggressive tumours. However, mitotic activity is low even in aggressive PA, in contrast to tumours arising from more rapidly replicating tissues, and pituitary tumours rarely progress to carcinoma (Chesnokova \& Melmed, 2010).

Indeed, induction of premature senescence in PA, which is triggered in response to aneuploidy, restrains further growth and malignant transformation but allows the cells to remain viable and perform their physiological functions.

Anyway, further studies are required to better understand all the genetic and epigenetic alterations accounting for the development of PA and the sequence with which they occur. 


\section{References}

Abdollahi, A., Pisarcik, D., Roberts, D., Weinstein, J., Cairns, P. \& Hamilton, T.C. (2003). LOT1 (PLAGL1/ZAC1), the candidate tumor suppressor gene at chromosome 6q24-25, is epigenetically regulated in cancer. The Journal of Biological Chemistry, Vol.278, No.8, pp.6041-6049, ISSN 0021-9258

Agarwal, S.K., Lee Burns, A., Sukhodolets, K.E., Kennedy, P.A., Obungu, V.H., Hickman, A.B., Mullendore, M.E., Whitten, I., Skarulis, M.C., Simonds, W.F., Mateo, C., Crabtree, J.S., Scacheri, P.C., Ji, Y., Novotny, E.A., Garrett-Beal, L., Ward, J.M., Libutti, S.K., Richard, A.H, Cerrato, A., Parisi, M.J., Santa Anna-A, S., Oliver, B., Chandrasekharappa, S.C., Collins, F.S., Spiegel, A.M. \& Marx, S.J. (2004). Molecular pathology of the MEN1 gene. Annals of the New York Academy of Sciences, Vol.1014, pp.189-198, ISSN 1749-6632

Al-Azzawi, H., Yacqub-Usman, K., Richardson, A., Hofland, L.J., Clayton, R.N. \& Farrell, W.E. (2011). Reversal of endogenous dopamine receptor silencing in pituitary cells augments receptor-mediated apoptosis. Endocrinology, Vol.152, No.2, pp.364-373, ISSN 0013-7227

Alvaro, V., Lévy, L., Dubray, C., Roche, A., Peillon, F., Quérat, B. \& Joubert D. (1993). Invasive human pituitary tumors express a point-mutated alpha-protein kinase-C. The Journal of Clinical Endocrinology and Metabolism, Vol.77, No.5, pp.1125-1129, ISSN 0021-972X

Alvaro, V., Prévostel, C., Joubert, D., Slosberg, E. \& Weinstein, B.I. (1997). Ectopic expression of a mutant form of PKCalpha originally found in human tumors: aberrant subcellular translocation and effects on growth control. Oncogene, Vol.14, No.6, pp.677-685, ISSN 0950-9232

Amaral, F.C., Torres, N., Saggioro, F., Neder, L., Machado, H.R., Silva, W.A. Jr, Moreira, A.C. \& Castro, M. (2009). MicroRNAs differentially expressed in ACTH-secreting pituitary tumors. The Journal of Clinical Endocrinology and Metabolism, Vol.94, No.1, pp.320-323, ISSN 0021-972X

Asa, S.L. \& Ezzat, S. (2002). The pathogenesis of pituitary tumours. Nature Reviews Cancer, Vol.2, No.11, pp.836-849, ISSN 1474-1768

Bahar, A., Bicknell, J.E., Simpson, D.J., Clayton, R.N. \& Farrell, W.E. (2004). Loss of expression of the growth inhibitory gene GADD45gamma, in human pituitary adenomas, is associated with CpG island methylation. Oncogene, Vol.23, No.4, pp.936-944, ISSN 0950-9232

Bartel, D. P. (2004). MicroRNAs: genomics, biogenesis, mechanism and function. Cell, Vol.116, No.2, pp.281-297, ISSN 0092-8674

Bassett, J.H., Forbes, S.A., Pannett, A.A., Lloyd, S.E., Christie, P.T., Wooding, C., Harding, B., Besser, G.M., Edwards, C.R., Monson, J.P., Sampson, J., Wass, J.A., Wheeler, M.H. \& Thakker, R.V. (1998). Characterization of mutations in patients with multiple endocrine neoplasia type 1. The American Journal of Human Genetics, Vol.62, No.2, pp.232-244, ISSN 1552-4825

Beckers, A. \& Daly, A.F. (2007). The clinical, pathological, and genetic features of familial isolated pituitary adenomas. European Journal of Endocrinology, Vol. 157, No. 4, pp. 371-382, ISSN 0804-4643

Bellodi, C., Krasnykh, O., Haynes, N., Theodoropoulou, M., Peng, G., Montanaro, L.\& Ruggero, D. (2010). Loss of function of the tumor suppressor DKC1 perturbs p27 
translation control and contributes to pituitary tumorigenesis. Cancer Research, Vol.70, No.14, pp.6026-6035, ISSN 0008-5472

Bilezikjian, L.M., Blount, A.L., Leal, A.M., Donaldson, C.J., Fischer, W.H. \& Vale, W.W. (2004). Autocrine/paracrine regulation of pituitary function by activin, inhibin and follistatin. Molecular and Cellular Endocrinology, Vol.225, No.1-2, pp.29-36, ISSN 0303-7207

Bottoni, A., Piccin, D., Tagliati, F., Luchin, A., Zatelli, M.C. \& degli Uberti, E.C. (2005). miR15a and miR-16-1 down-regulation in pituitary adenomas. Journal of Cellular Physiology, Vol.204, No.1, pp.280-285, ISSN 0021-9541

Bottoni, A., Zatelli, M.C., Ferracin, M., Tagliati, F., Piccin, D., Vignali, C., Calin, G.A., Negrini, M., Croce, C.M. \& Degli Uberti, E.C. (2007). Identification of differentially expressed microRNAs by microarray: a possible role for microRNA genes in pituitary adenomas. Journal of Cellular Physiology. Vol.210, No.2, pp.370-377, ISSN 0021-9541

Brandi, M.L., Gagel, R.F., Angeli, A., Bilezikian, J.P., Beck-Peccoz, P., Bordi, C., ConteDevolx, B., Falchetti, A., Gheri, R.G., Libroia, A., Lips, C.J., Lombardi, G., Mannelli, M., Pacini, F., Ponder, B.A., Raue, F., Skogseid, B., Tamburrano, G., Thakker, R.V., Thompson, N.W., Tomassetti, P., Tonelli, F., Wells, S.A.Jr \& Marx, S.J. (2001). Guidelines for diagnosis and therapy of MEN type 1 and type 2. The Journal of Clinical Endocrinology and Metabolism, Vol.86, No.12, pp.5658-5671, ISSN 0021-972X

Brook, C.G.D. \& Marshall, N.J. (2001). Essential Endocrinology (4th edition), Blackwell Science, ISBN 9780632056156-0632056150, Oxford, England

Chesnokova, V. \& Melmed, S. (2010). Pituitary senescence: the evolving role of Pttg. Molecular and Cellular Endocrinology, Vol.326, No.1-2, pp.55-59, ISSN 0303-7207

Clayton, R.N., Pfeifer, M., Atkinson, A.B., Belchetz, P., Wass, J.A., Kyrodimou, E., Vanderpump, M., Simpson, D., Bicknell, J. \& Farrell, W.E. (2000). Different patterns of allelic loss (loss of heterozygosity) in recurrent human pituitary tumors provide evidence for multiclonal origins. Clinical Cancer Research, Vol.6, No.10, pp.39733982, ISSN 1078-0432

Clayton, R.N. \& Farrell, W.E. (2004). Pituitary tumour clonality revisited. Frontiers of Hormone Research, Vol.32, pp.186-204, ISSN 1662-3762

Croce, C.M. (2009). Causes and consequences of microRNA dysregulation in cancer. Nature Reviews. Genetics, Vol.10, No.10, pp.704-714, ISSN 1471-0056

Dahia, P.L., Aguiar, R.C., Honegger, J., Fahlbush, R., Jordan, S., Lowe, D.G., Lu, X., Clayton, R.N., Besser, G.M. \& Grossman, A.B. (1998). Mutation and expression analysis of the p27/kip1 gene in corticotrophin-secreting tumours. Oncogene, Vol.16, No.1, pp.69-76, ISSN 0950-9232

Daly, A.F., Jaffrain-Rea, M.L. \& Beckers, A. (2005). Clinical and genetic features of familial pituitary adenomas. Hormone and metabolic research, Vol.37, No.6, pp.347-354, ISSN 0018-5043

Daly, A.F., Jaffrain-Rea, M.L., Ciccarelli, A., Valdes-Socin, H., Rohmer, V., Tamburrano, G., Borson-Chazot, C., Estour, B., Ciccarelli, E., Brue, T., Ferolla, P., Emy, P., Colao, A., De Menis, E., Lecomte, P., Penfornis, F., Delemer, B., Bertherat, J., Wemeau, J.L., De Herder, W., Archambeaud, F., Stevenaert, A., Calender, A., Murat, A., Cavagnini, F. \& Beckers, A. (2006). Clinical characterization of familial isolated pituitary adenomas. The Journal of Clinical Endocrinology and Metabolism, Vol.91, No.9, pp. 3316-3323, ISSN 0952-5041 
Daly, A.F., Vanbellinghen, J.F., Khoo, S.K., Jaffrain-Rea, M.L., Naves, L.A., Guitelman, M.A., Murat, A., Emy, P., Gimenez-Roqueplo, A.P., Tamburrano, G., Raverot, G., Barlier, A., De Herder, W., Penfornis, A., Ciccarelli, E., Estour, B., Lecomte, P., Gatta, B., Chabre, O., Sabate, M.I., Bertagna, X., Garcia Basavilbaso, N., Stalldecker, G., Colao, A., Ferolla, P., Wemeau, J.L., Caron, P., Sadoul, J.L., Oneto, A., Archambeaud, F., Calender, A., Sinilnikova, O., Montanana, C.F., Cavagnini, F., Hana, V., Solano, A., Delettieres, D., Luccio-Camelo, D.C., Basso, A., Rohmer, V., Brue, T., Bours, V., Teh, B.T. \& Beckers, A. (2007). Aryl hydrocarbon receptor-interacting protein gene mutations in familial isolated pituitary adenomas: analysis in 73 families. The Journal of Clinical Endocrinology and Metabolism, Vol.92, No.5, pp.1891-1896, ISSN 0952-5041

De Lellis, R.A., Lloyd, R.V., Heitz, P.U. \& Eng, C. (Eds) (2004). Pathology and genetics of tumours of endocrine organs, IARC Press, ISBN 9789283224167-9283224167, Lyon, France

De Martino, I., Visone, R., Palmieri, D., Cappabianca, P., Chieffi, P., Forzati, F., Barbieri, A., Kruhoffer, M., Lombardi, G., Fusco, A. \& Fedele M. (2007). The Mia/Cd-rap gene expression is downregulated by the high-mobility group A proteins in mouse pituitary adenomas. Endocrine Related Cancer, Vol.14, No.3, pp.875-886, ISSN 13510088

De Martino, I., Visone, R., Wierinckx, A., Palmieri, D., Ferraro, A., Cappabianca, P., Chiappetta, G., Forzati, F., Lombardi, G., Colao, A., Trouillas, J., Fedele, M. \& Fusco A. (2009). HMGA proteins up-regulate CCNB2 gene in mouse and human pituitary adenomas. Cancer Research, Vol.69, No.5, pp.1844-1850, ISSN 0008-5472

Edamatsu, H., Kaziro, Y. \& Itoh, H. (1998). Expression of an oncogenic mutant G alpha i2 activates Ras in Rat-1 fibroblast cells. FEBS Letters, Vol.440, No.1-2, pp.231-234, ISSN 0014-5793

Esteller, M. (2007). Cancer epigenomics: DNA methylomes and histone-modification maps. Nature Reviews Genetics, Vol.8, No.4, pp.286-298, ISSN 1471-0056

Evans, C.O., Moreno, C.S., Zhan, X., McCabe, M.T., Vertino, P.M., Desiderio, D.M. \& Oyesiku, N.M. (2008). Molecular pathogenesis of human prolactinomas identified by gene expression profiling, RT-qPCR, and proteomic analyses. Pituitary, Vol.11, No.3, pp.231-245, ISSN 1386-341X

Ezzat, S., Zheng, L., Zhu, X.F., Wu, G.E. \& Asa, S.L. (2002). Targeted expression of a human pituitary tumor-derived isoform of FGF receptor-4 recapitulates pituitary tumorigenesis. The Journal of Clinical Investigation, Vol.109, No.1, pp.69-78, ISSN 0021-9738

Fearon, E.R. (1997). Human cancer syndromes: clues to the origin and nature of cancer. Science, Vol.278, No.5340, pp.1043-1050, ISSN 0193-4511

Fedele, M., Battista, S., Kenyon, L., Baldassarre, G., Fidanza, V., Klein-Szanto, A.J., Parlow, A.F., Visone, R., Pierantoni, G.M., Outwater, E., Santoro, M., Croce, C.M. \& Fusco, A. (2002). Overexpression of the HMGA2 gene in transgenic mice leads to the onset of pituitary adenomas. Oncogene, Vol.21, No.20, pp.3190-3198, ISSN 0950-9232

Fedele, M., Pentimalli, F., Baldassarre, G., Battista, S., Klein-Szanto, A.J., Kenyon, L., Visone, R., De Martino, I., Ciarmiello, A., Arra, C., Viglietto, G., Croce, C.M. \& Fusco A. (2005). Transgenic mice overexpressing the wild-type form of the HMGA1 gene develop mixed growth hormone/prolactin cell pituitary adenomas and natural killer cell lymphomas. Oncogene, Vol.24, No.21, pp.3427-3435, ISSN 0950-9232 
Fedele, M., Visone, R., De Martino, I., Troncone, G., Palmieri, D., Battista, S., Ciarmiello, A., Pallante, P., Arra, C., Melillo, R.M., Helin, K., Croce, C.M. \& Fusco A. (2006). HMGA2 induces pituitary tumorigenesis by enhancing E2F1 activity. Cancer Cell, Vol.9, No.6, pp.459-471, ISSN 1535-6108

Fedele, M. \& Fusco, A. (2010). Role of the high mobility group A proteins in the regulation of pituitary cell cycle. The Journal of Molecular Endocrinolology, Vol.44, No.6, pp.309318, ISSN 0952-5041

Fedele, M., Palmieri, D. \& Fusco, A. (2010). HMGA2: A pituitary tumour subtype-specific oncogene? Molecular and Cellular Endocrinology, Vol.326, No.1-2, pp.19-24, ISSN 0303-7207

Finelli, P., Pierantoni, G.M., Giardino, D., Losa, M., Rodeschini, O., Fedele, M., Valtorta, E., Mortini, P., Croce, C.M., Larizza, L. \& Fusco, A. (2002). The High Mobility Group A2 gene is amplified and overexpressed in human prolactinomas. Cancer Research, Vol.62, No.8, pp.2398-2405, ISSN 0008-5472

Futreal, P.A., Coin, L., Marshall, M., Down, T., Hubbard, T., Wooster, R., Rahman, N. \& Stratton, M.R. (2004). A census of human cancer genes. Nature Reviews Cancer, Vol.4, No.3, pp.177-183, ISSN 1474-1768

Goodman, H.M. (2003). Basic Medical Endocrinology (3th edition), Academic Press, ISBN 9780122904219- 0122904214, Amsterdam, Netherlands

Groussin, L., Kirschner, L.S., Vincent-Dejean, C., Perlemoine, K., Jullian, E., Delemer, B., Zacharieva, S., Pignatelli, D., Carney, J.A., Luton, J.P., Bertagna, X., Stratakis, C.A. \& Bertherat, J. (2002). Molecular analysis of the cyclic AMP-dependent protein kinase A (PKA) regulatory subunit 1A (PRKAR1A) gene in patients with Carney complex and primary pigmented nodular adrenocortical disease (PPNAD) reveals novel mutations and clues for pathophysiology: augmented PKA signaling is associated with adrenal tumorigenesis in PPNAD. The American Journal of Human Genetics, Vol.71, No.6, pp.1433-1442, ISSN 1552-4825

Guru, S.C., Manickam, P., Crabtree, J.S., Olufemi, S.E., Agarwal, S.K., \& Debelenko LV. (1998). Identification and characterization of the multiple endocrine neoplasia type 1 (MEN1) gene. Journal of Internal Medicine, Vol.243, No.6, pp.433-439, ISSN 13652796

Hayward, B.E., Barlier, A., Korbonits, M., Grossman, A.B., Jacquet, P., Enjalbert, A. \& Bonthron, D.T. (2001). Imprinting of the G(s)alpha gene GNAS1 in the pathogenesis of acromegaly. The Journal of Clinical Investigation, Vol.107, No.6, pp. R31-36, ISSN 0021-972X

Heaney, A.P. \& Melmed, S. (2004). Molecular targets in pituitary tumours. Nature Reviews. Cancer, Vol.4, No.4, pp.285-295, ISSN 1474-1768

Hock, R., Furusawa, T., Ueda, T. \& Bustin, M. (2007). HMG chromosomal proteins in development and disease. Trends in Cell Biology, Vol.17, No.2, pp.72-79, ISSN 09628924

Hofland, L.J., Feelders, R.A., de Herder, W.W. \& Lamberts, S.W. (2010). Pituitary tumours: the sst/D2 receptors as molecular targets. Molecular and Cellular Endocrinology, Vol.326, No.1-2, pp.89-98, ISSN 0303-7207

Jaenisch, R. \& Bird, A. (2003). Epigenetic regulation of gene expression: how the genome integrates intrinsic and environmental signals. Nature Genetics, Vol.33, pp.245-254, ISSN 1061-4036 
Kaltsas, G.A., Nomikos, P., Kontogeorgos, G., Buchfelder, M. \& Grossman, A.B. (2005). Clinical review: Diagnosis and management of pituitary carcinomas. The Journal of Clinical Endocrinology and Metabolism, Vol.90, No.5, pp. 3089-3099, ISSN 1945-7197

Karnik, S.K., Hughes, C.M., Gu, X., Rozenblatt-Rosen, O., McLean, G.W., Xiong, Y., Meyerson, M., \& Kim, S.K. (2005). Menin regulates pancreatic islet growth by promoting histone methylation and expression of genes encoding p27Kip1 and p18INK4c. The Proceedings of the National Academy of Sciences U S A , Vol.102, No.41, pp.14659-14664, ISSN 0027-8424

Kirschner, L.S., Carney, J.A., Pack, S.D., Taymans, S.E., Giatzakis, C., Cho, Y.S., Cho-Chung, Y.S. \& Stratakis, C.A. (2000). Mutations of the gene encoding the protein kinase A type I-alpha regulatory subunit in patients with the Carney Complex. Nature Genetics, Vol.26, No.1, pp.89-92, ISSN 1061-4036

Knudson, A.G. (2001). Two genetic hits (more or less) to cancer, Nature Reviews Cancer, Vol.1, No.2, pp.157-162, ISSN 1474-1768

Landis, C.A., Masters, S.B., Spada, A., Pace, A.M., Bourne, H.R. \& Vallar, L. (1989). GTPase inhibiting mutations activate the alpha chain of Gs and stimulate adenylyl cyclase in human pituitary tumours. Nature, Vol.340, No.6236, pp.692-696, ISSN 0028-0836

Lania, A., Mantovani, G. \& Spada, A. (2003), Genetics of pituitary tumors: Focus on Gprotein mutations. Experimental Biology and Medicine (Maywood). Vol.228, No.9, pp.1004-1017, ISSN 1351-0088

Lemos, M.C. \& Thakker, R.V. (2008). Multiple endocrine neoplasia type 1 (MEN1): analysis of 1336 mutations reported in the first decade following identification of the gene. Human Mutation, Vol.29, No.1, pp.22-32, ISSN 1059-7794

Lyons, J., Landis, C.A., Harsh, G., Vallar, L., Grünewald, K., Feichtinger, H., Duh, Q.Y., Clark, O.H., Kawasaki, E., Bourne, H.R., et al. (1990). Two G protein oncogenes in human endocrine tumors. Science, Vol.249, No.4969, pp.655-659, ISSN 0193-4511

Mao, Z.G., He, D.S., Zhou, J., Yao, B., Xiao, W.W., Chen, C.H., Zhu, Y.H. \& Wang, H.J. (2010). Differential expression of microRNAs in GH-secreting pituitary adenomas. Diagnostic Pathology, Vol.5, No.1, pp.79-87, ISSN 1746-1596

Marx, S.J. \& Simonds, W.F. (2005). Hereditary hormone excess: genes, molecular pathways, and syndromes. Endocrine Reviews, Vol.26, No.5, pp.615-661, ISSN 0163-769X.

Matyakhina, L., Pack, S., Kirschner, L..S., Pak, E., Mannan, P., Jaikumar, J., Taymans, S.E., Sandrini, F., Carney, J.A., \& Stratakis, C.A. (2003). Chromosome 2 (2p16) abnormalities in Carney complex tumours. Journal of Medical Genetics, Vol.40, No.4, pp.268-277, ISSN 0022-2593

Mechenthaler, I. (2008). Galanin and the neuroendocrine axes. Cellular and Molecular Life Science, Vol.65, No.12, pp. 1826-1835, ISSN 1420-682X

Melmed, S. (2003). Mechanisms for pituitary tumorigenesis: the plastic pituitary. The Journal of Clinical Investigation, Vol.112, No.11, pp.1603-1618, ISSN 0021-9738

Melmed, S. \& Kleinberg, D. (2008). Anterior Pituitary, In: Williams Textbook of Endocrinology, H.M., Kronenberg, S. Melmed, K.S. Polonsky, P.R. Larsen (Eds.), 155-261, Sounders Elsevier, ISBN 978-1-4160-2911-3, Canada

Molatore, S. \& Pellegata, N.S. (2010). The MENX syndrome and p27: relationships with multiple endocrine neoplasia. Progress in Brain Research, Vol.182, pp.295-320, ISSN 0079-6123

Muşat, M., Morris, D.G., Korbonits, M. \& Grossman, A.B. (2010). Cyclins and their related proteins in pituitary tumourigenesis. Molecular and Cellular Endocrinolology, Vol.326, No.1-2, pp.25-29, ISSN 0303-7207 
Nagy, R., Sweet, K. \& Eng, C. (2004). Highly penetrant hereditary cancer syndromes. Oncogene, Vol.23, No.38, pp.6445-6470, ISSN 0950-9232

Occhi, G., Trivellin, G., Ceccato, F., De Lazzari, P., Giorgi, G., Demattè, S., Grimaldi, F., Castello, R., Davì, M.V., Arnaldi, G., Salviati, L., Opocher, G., Mantero, F. \& Scaroni, C. (2010). Prevalence of AIP mutations in a large series of sporadic Italian acromegalic patients and evaluation of CDKN1B status in acromegalic patients with multiple endocrine neoplasia. European Journal of Endocrinology, Vol.163, No.3, pp.369-376, ISSN 0804-4643

Ozfirat, Z. \& Korbonits, M. (2010). AIP gene and familial isolated pituitary adenomas. Molecular and Cellular Endocrinology, Vol.326, No.1-2, pp.71-79, ISSN 0303-7207

Pei, L. \& Melmed, S. (1997). Isolation and characterization of a pituitary tumor-transforming gene (PTTG). Molecular Endocrinology, Vol.11, No.4, pp.433-441, ISSN 0888-8809

Pellegata, N.S., Quintanilla-Martinez, L., Siggelkow, H., Samson, E., Bink, K., Hofler, H., Fend, F., Graw, J. \& Atkinson, M.J. (2006). Germline mutations in p27Kip1 cause a multiple endocrine neoplasia syndrome in rats and humans, Proc Natl Acad Sci U S A, Vol.103, No.42, pp.15558-15563, ISSN 0027-8424

Pernicone, P.J., Scheithauer, B.W., Sebo, T.J., Kovacs, K.T., Horvath, E., Young, W.F. Jr, Lloyd, R.V., Davis, D.H., Guthrie, B.L. \& Schoene, W.C. (1997). Pituitary carcinoma: a clinicopathologic study of 15 cases. Cancer, Vol.79, No.4, pp.804-812, ISSN 10970142

Pierantoni, G.M., Finelli, P., Valtorta, E., Giardino, D., Rodeschini, O., Esposito, F., Losa, M., Fusco, A. \& Larizza, L. (2005). High-mobility group A2 gene expression is frequently induced in non-functioning pituitary adenomas (NFPAs), even in the absence of chromosome 12 polysomy. Endocrine Related Cancer, Vol.12, No.4, pp.867-874, ISSN 1351-0088

Righi, A., Jin, L., Zhang, S., Stilling, G., Scheithauer, B.W., Kovacs, K. \& Lloyd, R.V. (2010). Identification and consequences of galectin-3 expression in pituitary tumors. Molecular and Cellular Endocrinology, Vol.326, No.1-2, pp.8-14, ISSN 0303-7207

Saeger, W., Lüdecke, D.K., Buchfelder, M., Fahlbusch, R., Quabbe, H.J. \& Petersenn, S. (2007). Pathohistological classification of pituitary tumors: 10 years of experience with the German Pituitary Tumor Registry. European Journal of Endocrinology, Vol.156, No.2 pp.203-216, ISSN 0804-4643

Schiemann, U., Assert, R., Moskopp, D., Gellner, R., Hengst, K., Gullotta, F., Domschke, W. \& Pfeiffer, A. (1997). Analysis of a protein kinase C-alpha mutation in human pituitary tumours. Journal of Endocrinology, Vol.153, No.1, pp.131-137, ISSN 00220795

Sharpless, N.E. \& DePinho, R.A. (2004). Telomeres, stem cells, senescence, and cancer. The Journal of Clinical Investigation, Vol.113, No.2, pp.160-168, ISSN 0021-9738

Scheithauer, B.W., Gaffey, T.A., Lloyd, R.V., Sebo, T.J., Kovacs, K.T., Horvath, E., Yapicier, O., Young, W.F. Jr, Meyer, F.B., Kuroki, T., Riehle, D.L., Laws, E.R. Jr. (2006). Pathobiology of pituitary adenomas and carcinomas. Neurosurgery, Vol.59, No.2, pp.341-353, ISSN 1528-8285

Schmidt, M.C., Henke, R.T., Stang, A.P., Meyer-Puttlitz, B., Stoffel-Wagner, B., Schramm, J. \& Von Deimling, A. (1999). Analysis of the MEN1 gene in sporadic pituitary adenomas. Journal of Pathology, Vol.188, pp.168-173, ISSN 0022-3417

Sherr, C.J. \& Roberts, J.M. (1999). CDK inhibitors: positive and negative regulators of G1phase progression. Genes Development, Vol.13, No.12, pp.1501-1512, ISSN 0890-9369 
Sidibé, E.H. (2007). Pituitary carcinoma. Anatomic and clinical features of cases reported in literature. Neurochirurgie, Vol.53, No.4, pp.284-288, ISSN 0028-3770

Simpson, D.J., Bicknell, J.E., McNicol, A.M., Clayton, R.N. \& Farrell, W.E. (1999). Hypermethylation of the p16/CDKN2A/MTSI gene and loss of protein expression is associated with nonfunctional pituitary adenomas but not somatotrophinomas. Genes Chromosomes Cancer, Vol.24, No.4, pp.328-336, ISSN 1045-2257

Simpson, D.J., Hibberts, N.A., McNicol, A.M., Clayton, R.N. \& Farrell, W.E. (2000). Loss of $\mathrm{pRb}$ expression in pituitary adenomas is associated with methylation of the RB1 CpG island. Cancer Research, Vol.60, No.5, pp.1211-1216, ISSN 0008-5472

Stratakis, C.A., Carney, J.A., Lin, J.P., Papanicolaou, D.A., Karl, M., Kastner, D.L., Pras, E. \& Chrousos, G.P. (1996). Carney complex, a familial multiple neoplasia and lentiginosis syndrome. Analysis of 11 kindreds and linkage to the short arm of chromosome 2. The Journal of Clinical Investigation, Vol. 97, No. 3, pp. 699-705, ISSN 0021-9738

Tateno, T., Zhu, X., Asa, S.L. \& Ezzat, S. (2010). Chromatin remodeling and histone modifications in pituitary tumors. Molecular and Cellular Endocrinology, Vol.326, No.1-2, pp.66-70, ISSN 0303-7207

Teh, B.T., Cardinal, J., Shepherd, J, Hayward, N.K., Weber, G., Cameron, D, \& Larsson, C. (1995). Genetic mapping of the multiple endocrine neoplasia type 1 locus at 11q13. Journal of Internal Medicine, Vol.238, No.3, pp.249-253, ISSN 1365-2796

Teh, B.T., Kytola, S., Farnebo, F., Bergman, L., Wong, F.K., Weber, G., Hayward, N., Larsson, C., Skogseid, B., Beckers, A., Phelan, C., Edwards, M., Epstein, M., Alford, F., Hurley, D., Grimmond, S., Silins, G., Walters, M., Stewart, C., Cardinal, J., Khodaei, S., Parente, F., Tranebjaerg, L., Jorde, R. \& Salmela, P. (1998). Mutation analysis of the MEN1 gene in multiple endocrine neoplasia type 1, familial acromegaly and familial isolated hyperparathyroidism. The Journal of Clinical Endocrinology and Metabolism, Vol.83, No.8, pp.2621-2626, ISSN 1945-7197

Thanos, D. \& Maniatis, T. (1995). Virus induction of human IFN beta gene expression requires the assembly of an enhanceosome. Cell, Vol.83, No.7, pp.1091-1100, ISSN 0092-8674

Theodoropoulou, M., Stalla, G.K. \& Spengler, D. (2010). ZAC1 target genes and pituitary tumorigenesis. Molecular and Cellular Endocrinology, Vol.326, No.1-2, pp.60-65, ISSN 0303-7207

Toledo, R.A., Lourenço, D.M. Jr, \& Toledo, S.P. (2010). Familial isolated pituitary adenoma: evidence for genetic heterogeneity. Frontiers of Hormone Research, Vol.38, pp.77-86, ISSN 0301-3073

Torrisani, J., Hanoun, N., Laurell, H., Lopez, F., Maoret, J.J., Souque, A., Susini, C., Cordelier, P. \& Buscail, L. (2008). Identification of an upstream promoter of the human somatostatin receptor, hSSTR2, which is controlled by epigenetic modifications. Endocrinology, Vol.149, No.6, pp.3137-3147, ISSN 0013-7227

Vallar, L., Spada, A. \& Giannattasio, G. (1987). Altered Gs and adenylate cyclase activity in human GH-secreting pituitary adenomas. Nature, Vol.330, No.6148, pp.566-568, ISSN 0028-0836

Vandeva, S., Jaffrain-Rea, M.L., Daly, A.F., Tichomirowa, M., Zacharieva, S. \& Beckers, A. (2010). The genetics of pituitary adenomas. Best Practice and Research. Clinical Endocrinology and Metabolism, Vol.24, No.3, pp.461-476, ISSN 1521-690X

Wang, E.L., Qian, Z.R., Rahman, M.M., Yoshimoto, K., Yamada, S., Kudo, E. \& Sano, T. (2010). Increased expression of HMGA1 correlates with tumour invasiveness and 
proliferation in human pituitary adenomas. Histopathology, Vol.56, No.4, pp.501509, ISSN 0309-0167

Weinstein, L.S., Shenker. A., Gejman. P.V., Merino. M.J., Friedman. E. \& Spiegel, A.M. (1991). Activating mutations of the stimulatory G protein in the McCune-Albright syndrome. The New England Journal of Medicine, Vol.325, No.24, pp.1688-1695, ISSN 0028-4793

Wenbin, C., Asai, A., Teramoto, A., Sanno, N. \& Kirino, T. (1999). Mutations of the MEN1 tumor suppressor gene in sporadic pituitary tumors. Cancer Letters, Vol.142, No.1, pp.43-47, ISSN 0304-3835

Wierinckx, A., Auger, C., Devauchelle, P., Reynaud, A., Chevallier, P., Jan, M., Perrin, G., Fèvre-Montange, M., Rey, C., Figarella-Branger, D., Raverot, G., Belin, M.F., Lachuer, J. \& Trouillas J. (2007). A diagnostic marker set for invasion, proliferation, and aggressiveness of prolactin pituitary tumors. Endocrine Related Cancer, Vol.14, No.3, pp.887-900, ISSN 1351-0088

Williamson, E.A., Daniels, M., Foster, S., Kelly, W.F., Kendall-Taylor, P. \& Harris, P.E. (1994). Gs alpha and Gi2 alpha mutations in clinically non-functioning pituitary tumours. Clinical Endocrinology, Vol.41, No.6, pp.815-820, ISSN 0300-0664

Yoshino, A., Katayama, Y., Ogino, A., Watanabe, T., Yachi, K., Ohta, T., Komine, C., Yokoyama, T. \& Fukushima, T. (2007). Promoter hypermethylation profile of cell cycle regulator genes in pituitary adenomas. Journal of Neuro-oncology, Vol.83, No.2, pp.153-162, ISSN 0167-594X

Zhang, X., Horwitz, G.A., Heaney, A.P., Nakashima, M., Prezant, T.R., Bronstein, M.D. \& Melmed S. (1999). Pituitary tumor transforming gene (PTTG) expression in pituitary adenomas. The Journal of Clinical Endocrinology and Metabolism, Vol.84, No.2, pp.761-767, ISSN 1945-7197

Zhang, X., Sun, H., Danila, D.C., Johnson, S.R., Zhou, Y., Swearingen, B. \& Klibanski, A. (2002). Loss of expression of GADD45 gamma, a growth inhibitory gene, in human pituitary adenomas: implications for tumorigenesis. The Journal of Clinical Endocrinology and Metabolism, Vol.87, No.3, pp.1262-1267, ISSN 0021-972X

Zhang, X., Zhou, Y. \& Klibanski, A. (2010). Isolation and characterization of novel pituitary tumor related genes: a cDNA representational difference approach. Molecular and Cellular Endocrinology, Vol.326, No.1-2, pp.40-47, ISSN 0303-7207

Zhao, J., Dahle, D., Zhou, Y., Zhang, X. \& Klibanski, A. (2005). Hypermethylation of the promoter region is associated with the loss of MEG3 gene expression in human pituitary tumors. The Journal of Clinical Endocrinology and Metabolism, Vol.90, No.4, pp.2179-2186, ISSN 0021-972X

Zhu, X., Mao, X., Hurren, R., Schimmer, A.D., Ezzat, S. \& Asa, S.L. (2008). Deoxyribonucleic acid methyltransferase $3 \mathrm{~B}$ promotes epigenetic silencing through histone 3 chromatin modifications in pituitary cells. The Journal of Clinical Endocrinology and Metabolism, Vol.93, No.9, pp.3610-3617, ISSN 0021-972X

Zhuang, Z., Ezzat, S.Z,. Vortmeyer, A.O., Weil, R., Oldfield, E.H., Park, W.S., Pack, S., Huang, S., Agarwal, S.K., Guru, S.C., Manickam, P., Debelenko, L.V., Kester, M.B., Olufemi, S.E., Heppner, C., Crabtree, J.S., Burns, A.L., Spiegel, A.M., Marx, S.J., Chandrasekharappa, S.C., Collins, F.S., Emmert-Buck, M.R., Liotta, L.A., Asa, S.L. \& Lubensky, I.A. (1997). Mutations of the MEN1 tumor suppressor gene in pituitary tumors. Cancer Research, Vol.57, No.24, pp.5446-5451, ISSN 0008-5472 


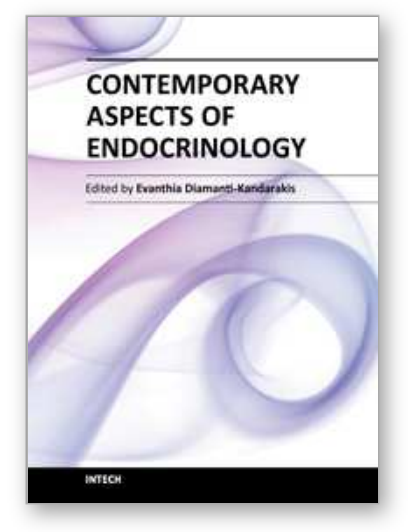

\author{
Contemporary Aspects of Endocrinology \\ Edited by Dr. Evanthia Diamanti-Kandarakis
}

ISBN 978-953-307-357-6

Hard cover, 454 pages

Publisher InTech

Published online 30, November, 2011

Published in print edition November, 2011

This book aims to provide readers with a general as well as an advanced overview of the key trends in endocrine disorders. While covering a variety of topics ranging from thyroid carcinogenesis and pituitary adenomas to adrenal tumors and metabolic bone disease, this book also focuses on more specific issues not yet fully elucidated (e.g. the molecular pathways involved in thyrotropin beta gene regulation or monogenic phosphate balance disorders). Readers of different fields and background will have the opportunity to update their knowledge and more importantly to clarify areas of uncertainty and controversies in several topics of endocrine disorders.

\title{
How to reference
}

In order to correctly reference this scholarly work, feel free to copy and paste the following:

Monica Fedele, Giovanna Maria Pierantoni and Alfredo Fusco (2011). The Genetics of Pituitary Adenomas, Contemporary Aspects of Endocrinology, Dr. Evanthia Diamanti-Kandarakis (Ed.), ISBN: 978-953-307-357-6, InTech, Available from: http://www.intechopen.com/books/contemporary-aspects-of-endocrinology/thegenetics-of-pituitary-adenomas

\section{INTECH}

open science | open minds

\section{InTech Europe}

University Campus STeP Ri Slavka Krautzeka 83/A 51000 Rijeka, Croatia Phone: +385 (51) 770447

Fax: +385 (51) 686166 www.intechopen.com

\section{InTech China}

Unit 405, Office Block, Hotel Equatorial Shanghai No.65, Yan An Road (West), Shanghai, 200040, China 中国上海市延安西路65号上海国际贵都大饭店办公楼 405 单元 Phone: $+86-21-62489820$

Fax: $+86-21-62489821$ 
(C) 2011 The Author(s). Licensee IntechOpen. This is an open access article distributed under the terms of the Creative Commons Attribution 3.0 License, which permits unrestricted use, distribution, and reproduction in any medium, provided the original work is properly cited. 